\title{
Liudmyla Lovinska
}

Dr. Sc. (Economics), Professor, Member of Methodological Board on Accounting under the Ministry of Finance of Ukraine, SESE "The Academy of Financial Management", Kyiv, Ukraine, lovinska@ukr.net ORCID ID: http://orcid.org/0000-0001-5427-7185

\section{Svitlana Levitska}

Dr. Sc. (Economics), Professor, National University of Water and Environmental Engineering, Rivne, Ukraine, levitska.svitlana@yahoo.com ORCID ID: https://orcid.org/0000-0001-7803-5586

\section{Nataliia Sushko}

Ph. D. (Economics), Associate Professor, SESE "The Academy of Financial Management", Kyiv, Ukraine, nisushko@ukr.net ORCID ID: https://orcid.org/0000-0003-2603-2871

\section{MEASUREMENT OF REVENUE OF HIGHER EDUCATION STATE INSTITUTIONS ON THE PRINCIPLES OF REFORMED BUDGET ACCOUNTING}

\begin{abstract}
The article summarizes the practical experience of implementing a reformed methodology for accounting the activities of domestic budget institutions on the example of revenue recognition of higher education state institutions. This article outlines the basic requirements for budget planning, control over the targeted rational use of budget funds that specify an appropriate classification of revenues as objects of accounting and their objective measurement. The objective of the article is: generalization of issues discussed at the stages of implementing the reformed revenue recognition of budget institutions on the examples of HEIs; justification of an alternative to measure economic rewards of transactions financed from budget funds and own revenues. The main tasks of the study are: an estimate of the application of revenue recognition principles of higher education state institutions as for their compliance with the International Accounting Standards for the public sector, ensuring the reliability of accounting data, taking into account the regulatory framework for the allocation and accounting of budgetary funds in Ukraine. The article presents an analysis of the transformation of revenue recognition arising from exchange and non-exchange business transactions. Alternatives to supplement the current National Accounting Standards (standard) for the public sector "Revenues" on the classification of revenues, their presentation in the accounts are proposed on the outcome of the analysis. Detailing the time, form, intended use of the received economic benefit in the form of assets causes the need for a qualitative expansion of the measurement of revenue recognition through the valuation of: economic benefits (cash inflows received as a result of transactions of an entrepreneurial nature), socio-economic benefits (economic benefits, measurement of which takes into account both direct acquisition of assets, as well as a documented measurement of the impact of the transaction on enhancing economic benefits on the outcome of the social program implementation), socio-economic effect (intangible socio-economic benefits received by HEIs).
\end{abstract}

Keywords: budget accounting, revenues from exchange operations, budget institutions, higher education institutions, national accounting standards.

JEL classification: M400.

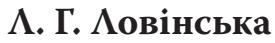 \\ доктор економічних наук, професор, член Методологічної ради з бухгалтерського обліку \\ при Міністерстві фінансів України, заступник директора з наукової роботи НДФІ \\ ДННУ “Академія фінансового управління", Київ, Україна, lovinska@ukr.net \\ ORCID ID: http://orcid.org/0000-0001-5427-7185
}

(c) Аовінська А. Г., Аевицька С. О., Сушко Н. І., 2019 


\title{
С. О. Мевицька
}

доктор економічних наук, професор, професор кафедри обліку і аудиту Національного університету водного господарства та природокористування, Рівне, Україна, levitska.svitlana@yahoo.com ORCID ID: https://orcid.org/0000-0001-7803-5586

\section{H. I. Сушко}

кандидат економічних наук, доцент, завідувач відділу методології бухгалтерського обліку НДФІ ДННУ “Академія фінансового управління", Київ, Україна, nisushko@ukr.net ORCID ID: https://orcid.org/0000-0003-2603-2871

\section{ОЦІНКА АОХОАІВ АЕРЖАВНИХ ЗАКАААІВ ВИЩОЇ ОСВІТИ ЗА ПРИНЦИПАМИ РЕФОРМОВАНОГО БЮАЖЕТНОГО ОБАІКУ}

Анотація. У статті узагаАьнено практичний досвіА упровадження реформованої методики обліку Аіяльності вітчизняних бюАжетних установ на прикцаАі обліку Аоходів Аержавних закладів вищої освіти (ЗВО). Основною метою проведеного Аослідження $\epsilon$ оцінка застосування принципів обліку Аоходів Аержавних ЗВО на предмет їх віАповіАності Міжнародним стандартам обціку Аля Аержавного сектору, забезпечення Аостовірності облікових Ааних з урахуванням нормативної бази розподіку та обліку бюАжетних коштів в Україні. ПровеАено аналіз трансформації обліку доходів віА обмінних і необмінних господарських операцій, за резумьтатами якого запропоновано альтернативи щодо Аоповнення чинного Націона ьного поможення (стандарту) бухгалтерського обліку Аля Аержавного сектору “Аоходи" 3 питань кцасифікації доходів, їх відображення на рахунках бухгалтерського обліку.

КАючові слова: бюАжетний облік, Аоходи віА обмінних операцій, бюАжетні установи, закцаАи вищої освіти, Націона ьні станАарти бухга ттерського обціку.

Табц. 2. Рис. 3. Міт. 14.

\section{$\Lambda$. Г. Аовинская}

доктор экономических наук, профессор, член Методологического совета по бухгалтерскому учету при Министерстве финансов Украины, заместитель директора по научной работе НИФИ ГУНУ “Академия финансового управления", Киев, Украина

\section{С. А. Мевицкая}

доктор экономических наук, профессор, профессор кафедры учета и аудита Национального университета водного хозяйства и природопользования, Ровно, Украина

\section{Н. И. Сушко}

кандидат экономических наук, доцент, заведующая отделом методологии бухгалтерского учета НИФИ ГУНУ “Академия финансового управления", Киев, Украина

\section{ОЦЕНКА АОХОАОВ ГОСУААРСТВЕННЫХ ЗАВЕАЕНИЙ ВЫСШЕГО ОБРАЗОВАНИЯ ПО ПРИНЦИПАМ РЕФОРМИРОВАННОГО БЮАЖЕТНОГО УЧЕТА}

\begin{abstract}
Аннотация. В статье обобщен практический опыт внеАрения реформированной методики учета Аеятельности отечественных бюАжетных учреждений на примере учета Аоходов государственных заведений высшего образования (ЗВО). Основной целью проведенного исследования явцяется оценка применения принципов учета Аоходов государственных ЗВО на преАмет их соответствия МежАународным станАартам учета ААя государственного сектора, обеспечения достоверности учетных Аанных с учетом нормативной базы распределения и учета бюАжетных среАств в Украине. Осуществлен анализ трансформации учета доходов от обменных и необменных хозяйственных операций, по результатам которого предложены альтернативы, касающиеся Аополнения действующего Национального положения (стандарта) бухгалтерского учета Аля государственного сектора “Аоходы” по классификации доходов, их отражения на счетах бухгалтерского учета.
\end{abstract}


Кмючевые слова: бюджетный учет, доходы от обменных операций, бюджетные учреждения, заведения высшего образования, Национацьные стандарты бухгалтерского учета.

The strategy of updating the accounting system in budget institutions are aimed at creating a unified information provision of the economic activity of public sector entities (other than state-owned enterprises), at the stages of its completion. The main objective of the Strategy is to provide the activity management of higher education state institutions with effective accounting and analytical information that meets the principles of International Public Sector Accounting Standards (IPSAS).

The most controversial issues at the stages of the implementation of National Public Sector Accounting Standards (NPSAS) are the methods of accounting for revenues and expenses of budget institutions, including higher education state institutions (hereinafter referred to as HEIs).

Current requirements for budget planning, control over the targeted rational use of budget funds give rise to an appropriate classification of revenues as objects of accounting, their objective measurement, high analytical level of registration on accounts and in the financial reporting statement.

Revenues and expenses arising from exchange and non-exchange transactions are important indicators of the updated forms of financial reporting. In 2017 for the first time The Ministry of Education and Science (MES) of Ukraine produced financial statements in accordance with NPSAS 101 "Presentation of Financial Statements". In particular, the analysis of statement No. 2 "Financial results statement" makes it possible to draw the following conclusions.

The total amount of revenues received in 2017 is 55,264.6 million UAH, of which 31,183.3 million UAH (56.43\%) accounts for revenues arising from exchange transactions, 24,081.3 million UAH (43.57\%) revenues arising from non-exchange transactions. The structure of revenues arising from exchange and non-exchange transactions is shown in Figure 1.
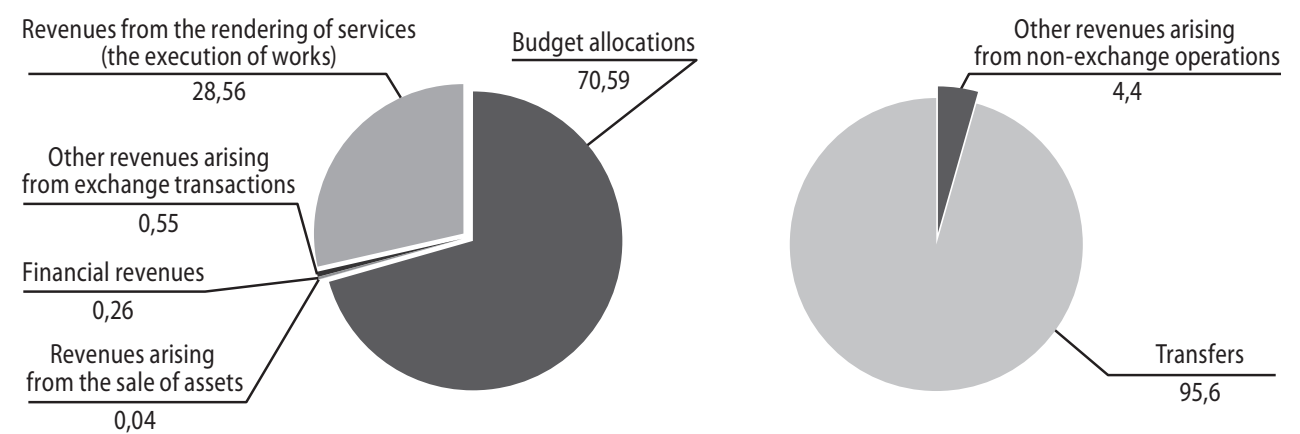

\section{Fi gure 1. Significant share of revenues arising from exchange and non-exchange transactions of MES in 2017, \%}

Source: Ministry of Education and Science of Ukraine. (2018). Consolidated report of the Ministry of Education and Science for 2017. Retrieved from https://mon.gov.ua/storage/app/media/budzhet/ 2018/04/03/zvit-mon-za-2017-rik.pdf [in Ukrainian]. 
Among revenues arising from exchange transactions, the largest share is budget allocations (70.59\%) and revenues from the rendering of services (the execution of works) (28.56\%). Transfers (95.55\%) occupy the largest share in the overall structure of revenues arising from non-exchange transactions.

Total amount of expenses for 2017 is 57,541.2 million UAH, of which 29,114.3 million UAH (50.60\%) accounts for expenses from exchange transactions, 28,427.0 million UAH (49.40\%) - expenses from non-exchange transactions [1]. The structure of expenses for exchange and non-exchange transactions is shown in Figure 2.

Among expenses from exchange transactions, the largest share falls on budget programs (67.89\%) and production costs (services, works) (30.85\%). Transfers (80.93\%) occupy the largest share in the total structure of expenses from nonexchange transactions.

According to the Monthly Report on the State Budget of Ukraine for JanuaryDecember 2017, published on the official website of the State Treasury Service of Ukraine, expenses under budget program 2201160 “Training of Personnel by Higher Educational Institutions of the III and IV Accreditation Levels and Ensuring Their Practice Bases" amounted to 20,334.8 million UAH, which is $2.42 \%$ of the total State Budget expenditures and 0.68\% of GDP in 2017 [1].

Such ratios of revenues and expenses from exchange and non-exchange transactions update requirements to ensure their objective measurement as an efficiency factor for financing innovative educational projects at the stages of European integration processes.

The methodology and organization of accounting and analytical support for the activities of budget institutions, measurement of assets and outcomes of their financial and economic activities were presented in the scientific works of many Ukrainian scholars: P. Y. Atamas, N. V. Artemenko, O. O. Doroshenko, S. V. Svirko, O. O. Osadchaya, K. M. Romashchenko [2-6] et al.

Reforming budget accounting requires further research of the issues of alternative choices of methods for resources, capital and financial results
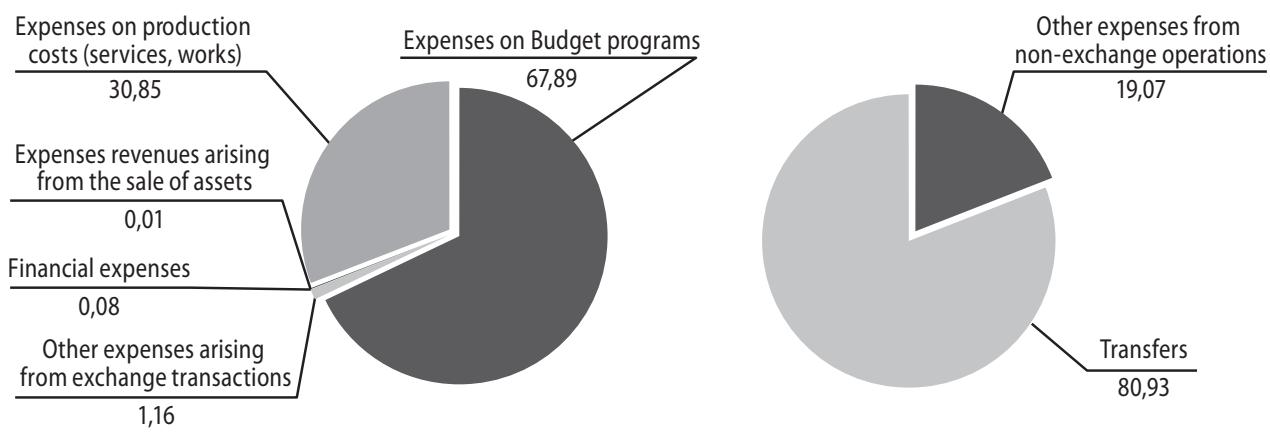

\section{Figure 2. Significant share of expenses from exchange and non-exchange transactions of MES in 2017, \%}

Source: Ministry of Education and Science of Ukraine. (2018). Consolidated report of the Ministry of Education and Science for 2017. Retrieved from https://mon.gov.ua/storage/app/media/budzhet/ 2018/04/03/zvit-mon-za-2017-rik.pdf [in Ukrainian]. 
accounting, efforts for their practical implementation as an indispensable factor of the relevance of accounting indicators on transactions' outcomes that have targeted financing from the budget.

The objective of the article is: generalization of issues discussed at the stages of implementing the reformed revenue recognition of budget institutions on the examples of HEIs, in particular, clarifying the criteria for presenting exchange and non-exchange transactions in accounts; justification of an alternative to measure economic rewards of transactions financed from budget funds and own revenues.

National Public Sector Accounting Standards 124 "Revenue" (NPSAS 124) regulates the revenue classification by groups:

1. Revenues arising from exchange transactions: received budget allocations by an institution; revenue from the provision of paid educational and other services (the execution of works); revenue from the sale (revenue from operations with capital, gains from the sale of real estate); revenue from interest, royalty and dividends; other revenues arising from exchange transactions. At the heart of such revenues is the transfer of possession for services (goods, products), its documented monetary evaluation, as well as an estimate of the costs associated with such revenues.

2. Revenues arising from non-exchange operations: funds received by HEIs from enterprises, organizations, individuals, other budget institutions for the implementation of targeted efforts; non-repayable obligations [7].

Article 13 of the Budget Code of Ukraine HEIs' own revenue received in addition to the resources of the general budgetary fund and are included in the special fund of the budget, divides into groups and subgroups, the classification of which is shown in Figure 3 on the example of HEIs.

The Budget Code of Ukraine treats public sector entities revenue as own receipts from:

- exchange transactions - group No. 1 completely and subgroups 2, 3, 4 groups No. 2;

- non-exchange transactions - group No. 2 (subgroup 1).

Based on NPSAS 124, HEIs' exchange transactions are also classified as budgetary allocation. Note: NPSAS 124 was developed on the basis of two international standards (such as IPSAS 9, Revenue arising from Exchange Transactions [8] and IPSAS 23, Revenue arising from Non-exchange Transactions (Taxes and Transfers) [9]). Therefore, there are some differences between domestic and international accounting approaches:

- according to the international practice, accounting of budget institutions' revenue (including HEIs) is conducted applying two standards, while the national standard combines accounting of revenue arising from exchange and nonexchange transactions;

- with the introduction of NPSAS 124: a new terminology of the objects of accounting ("revenue arising from exchange transactions ", "revenue arising from non-exchange transactions") is applied; there has occurred an increase in the composition of public sector revenues; the criteria for recognition of each type of revenues, their measurement are specified. 


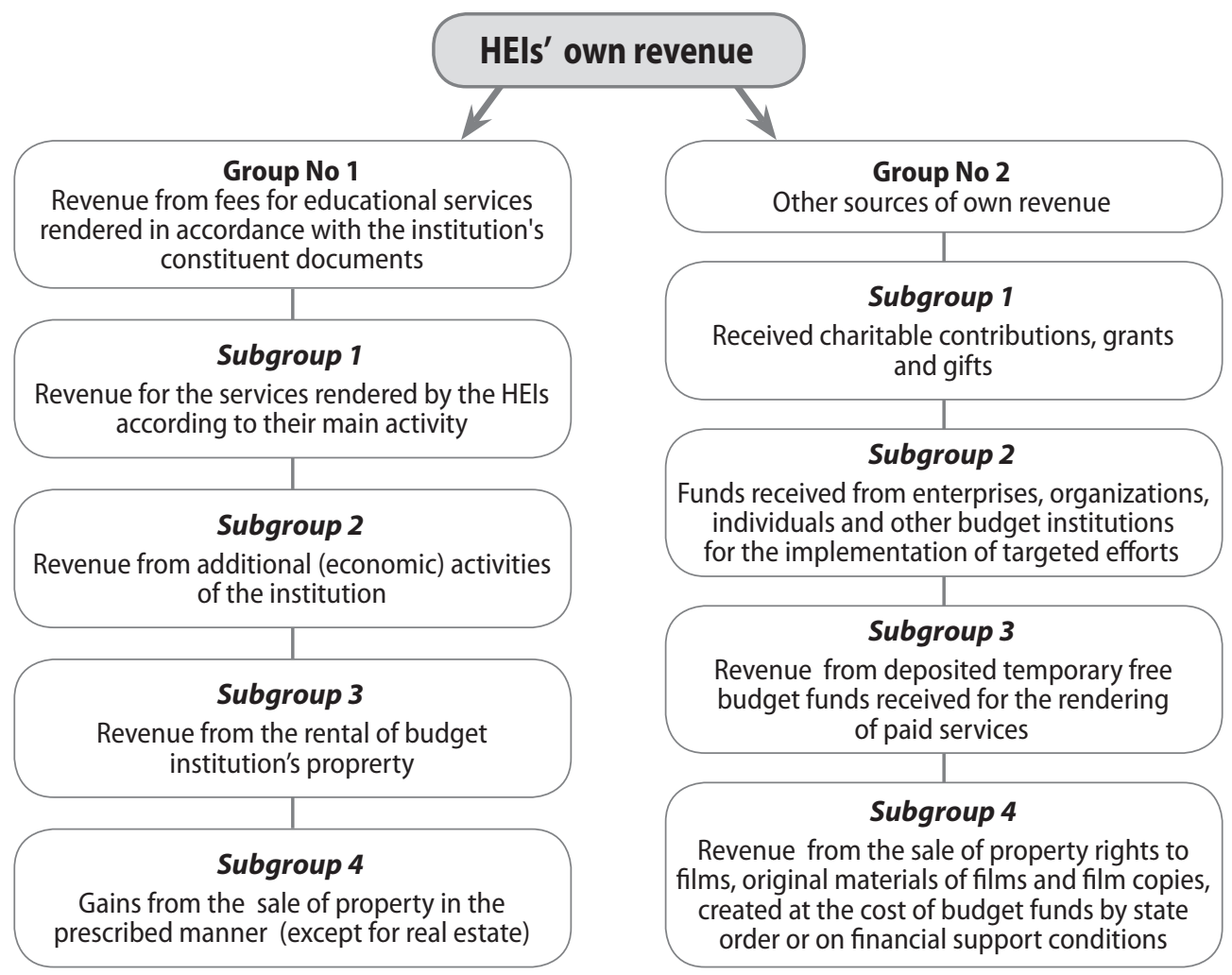

Figure 3. Own revenue of budget institutions (on the example of HEIs)

Source: Verkhovna Rada of Ukraine. (2010). Budget Code of Ukraine. (Act No. 2456-VI, July 8). Retrieved from https://zakon.rada.gov.ua/laws/show/2456-17 [in Ukrainian].

Revenue arising from both exchange and non-exchange transactions (except for services in kind) is recognized as an asset if:

- there is a probability that the public sector entity will receive future economic benefits or asset-related service potential;

- it is possible to measure reliably the fair value of the asset;

- the public sector entity receives control over resources (the main element of control is the ability to block or regulate the access of other public sector entities to the asset's benefits), risks and management over the acquired asset.

Unfortunately, such detailing in the identification of an asset by budget institutions in the national accounting standards is absent.

IPSAS 9 "Revenue arising from Exchange Transactions" focuses on certain aspects of revenue recognition, namely:

- revenue comprises only the gross inflow of economic benefits or service potential received and / or receivable by the entity on its own account;

- amounts collected by the entity as an agent of a public authority or on behalf of third parties are not economic benefits or service potential, as they do not result in an inhancement of assets or a decrease of liabilities. 
Financial inflows do not correspond to the definition of revenue, namely borrowings: they cause similar changes in both assets and liabilities; do not affect net assets / equity (the latter are directly presented in the statement of financial position and added to the balance of assets and liabilities).

In general, NPSAS 124 treats exchange transactions in a similar way. However, IPSAS 9 treats in detail (unlike the domestic accounting standard) revenue recognition separately to barter transactions, rental, interest, royalties and dividends, and sales of goods (finished goods and services). The following are the points raised by the conceptual reservations of the Standard for service revenue recognition (which is of importance for HEIs).

1. If the outcome of the transaction related to rendering services can be estimated reliably, revenue is recognized by reference to the stage of completion of the transaction existing at the reporting date (by the phased implementation method).

2. Revenue measurement reliability is ensured when the following conditions are simultaneously met: it is possible to measure the amount of revenue; there is a probability that an entity receives economic benefits or service potential associated with the transaction; the stage of completeness of the transaction is to be measured at the reporting date; it is possible to accurately measure the costs incurred for the transaction and the costs necessary to complete it.

3. The stage of completeness of the operation is determined in different ways: survey of the work performed; estimation of the volume of services rendered in the total amount of services scheduled and pre-estimated before rendering; estimation of the proportion of costs incurred at a certain date in the preestimated total cost of the transaction. In this case, only expenses that are subject to documentation reflect a particular stage of services (it is these costs that are included in the pre-estimated total transaction costs).

4. In the event of difficulties with the costs estimation which must be recovered, revenue is not recognized, and incurred costs are recognized as expenses.

On the outcome of the sale of works, products, goods, revenue is recognized when the following conditions are simultaneously met: the entity has transferred to the buyer significant risks and rewards associated with the ownership of the goods; the entity does not retain a permanent participation in management at the level associated with ownership, it has no effective control over the goods sold; the amount of revenue can be measured reliably; it is probable that economic benefits or service potential associated with the transaction will be received by the entity; the costs incurred or to be incurred related to the transaction can be measured reliably.

In some cases, the transfer of risks and rewards of ownership does not occur simultaneously with the transfer of legal title or passing of possession: transaction is not a sale, revenue is not recognized. When the entity retains only an insignificant risk of ownership, the transaction is considered to be a sale and revenue is recognized.

NPSAS 124 treats revenues arising from exchange transactions for domestic public sector entities (including for HEIs) more generally, depending on the nature of the transaction: 
- revenue arising from exchange transaction is recognized when there is a probability of receiving by HEIs economic benefits or service potential associated with the transaction;

- budget allocations are recognized as a revenue on recognizing incurred expenses related to the institution's performance of the powers defined by the legislation and constituent documents or receiving an asset, services (works) for the implementation of activities which are not related to the main activity;

- revenue related to the rendering of services (the execution of works) is recognized to the extent of completeness of the transaction for the rendering of services (the execution of works) at the balance sheet date, if the outcome of the transaction can be reliably estimated;

- in respect of "other revenues" (in particular, revenues arising from exchange differences, the sale of assets (other than real estate), asset revaluation within the amount of the previous write-down, etc.) - they are measured within the amount of recognized revenue.

The following revenues arising from exchange transactions are not recognized (similar to IPSAS 9): value added tax, excise tax, other tax revenues to be transferred to the budget and funds of compulsory state social insurance; the amount of prepayment (advance) in payment for goods, works and services; the amount of a deposit on security or in repayment of a budget loan (credit) when stipulated by the legislation; revenues belonging to other persons (item 2.1. NPSAS 124).

Groups of non-exchange transactions include transactions by which the institution: receives resources without paying for them directly, or payment is of nominal character; can pay a certain compensation for the received resources, but such compensation is not equal to the fair value of the received resources. Among non-exchange transactions are amounts, collected by a representative of the public authority or other government organization, that the entity receives and do not result in an increase in assets or a decrease in liabilities.

Under IPSAS 23, a non-exchange transaction is treated in a more detailed manner: when a non-exchange transaction is performed, one public sector entity receives resources from another entity without reimbursing their value or transfers resources to another public sector entity without receiving roughly equivalent compensation. NPSAS 124, unfortunately, does not detail the terms of the agreements for the recognition of transfers.

Domestic HEIs recognize / do not recognize revenues arising from nonexchange transactions in the following order:

1. Revenue from transfers in the case of a specific purpose (subvention, etc.) is recognized at the period of receipt of budget funds provided by the relevant estimate of the institution.

2. Free goods, works, and services in kind may be recognized by HEIs as a revenue and asset of the reporting period actually received at their fair value.

3. Amounts of external free aid are recognized as an asset (receivables) and revenue with enforcement of the contract.

4. Amounts of internal free aid are recognized as an asset and revenue of the reporting period in which they were received. 
5. Amounts of fines, penalties, received on the decision of the parties to the agreement or relevant state bodies, courts, are included in the revenue of the reporting period on the date of their actual receipt.

6. Revenue of the reporting period is the amount of the non-repayable budget obligations written off in this reporting period (except for accounts payable, the limitation period of which has expired).

Sufficiently ambiguous in the normative basis of budget accounting are the approaches to measuring revenues. In accordance with NPSAS 124, measurement of revenue from transactions related to the rendering of services, goods sales, and works as a whole does not differ from IPSAS 9. Note that, according to NPSAS 101 IPSASs concerning the compliance with the principle of prudence (which, in the current version of the Law of Ukraine "On Accounting and Financial Reporting" Is absent!), revenue is recognized when there is a probability that the entity will receive economic benefits or service potential associated with the transaction.

The comparison of revenue recognition methods and its measurement from exchange transactions in international and domestic accounting practices are presented in Table 1.

The main differences between the international and domestic accounting regulatory framework regarding the methodology for revenue measurement of public sector entities (including HEIs) from non-exchange transactions (except for taxes and transfers that are estimated at their original value at the time of receipt on treasury / bank accounts) are given in Table 2.

\section{Table 1. Measurement of revenue from exchange transactions for public sector entities}

\begin{tabular}{|c|c|c|c|}
\hline \multirow[t]{2}{*}{ No. } & \multirow{2}{*}{$\begin{array}{l}\text { Economic } \\
\text { transactions }\end{array}$} & $\begin{array}{c}\text { International accounting } \\
\text { practice }[8 ; 10]\end{array}$ & Domestic accounting practice $[7 ; 11 ; 12]$ \\
\hline & & Measurement & Measurement \\
\hline 1 & $\begin{array}{l}\text { Barter (exclusively } \\
\text { within own } \\
\text { revenues } \\
\text { transaction })^{*} \\
\end{array}$ & At the fair value & $\begin{array}{l}\text { At the original value stipulated in the sales contract } \\
\text { (in accordance with shipment documents / } \\
\text { acceptance certificate), but lower than the fair value } \\
\text { of the transferred goods/services rendered }\end{array}$ \\
\hline 2 & Rent (operating) & At the fair value & $\begin{array}{l}\text { At the original value determined by the rental } \\
\text { agreement }\end{array}$ \\
\hline 3 & Receiving interest & At the fair value & $\begin{array}{c}\text { At the original value which is equal to the amount } \\
\text { of interests stipulated on a contractual basis } \\
\text { by the parties to such transactions }\end{array}$ \\
\hline 4 & Royalty & At the fair value & $\begin{array}{l}\text { At the original value stipulated by the agreement } \\
\text { of the respective parties }\end{array}$ \\
\hline 5 & Dividends & At the fair value & $\begin{array}{c}\text { At the original value which is equal to the amount } \\
\text { of dividends established by the decision } \\
\text { of the meeting of shareholders/owners }\end{array}$ \\
\hline 6 & $\begin{array}{l}\text { The sale of goods } \\
\text { (finished goods, } \\
\text { services) }\end{array}$ & At the fair value & $\begin{array}{c}\text { At the original value, stipulated in the sales contract / } \\
\text { the rendering of services (respectively, according } \\
\text { to the documents of the seller) }\end{array}$ \\
\hline
\end{tabular}

*According to item 6. Article 45 of the Budget Code of Ukraine it is prohibited conducting settlements with the budget in a non-monetary form, including by way of mutual settlements, the use of bills, barter transactions and the settlement of counterclaims at financial institutions, except for operations related to public debts, and when it is stipulated by the law on the State Budget of Ukraine. 
Table 2. Measurement of revenue arising from non-exchange transactions

\begin{tabular}{|c|c|c|c|c|c|}
\hline \multirow{2}{*}{ No. } & \multirow{2}{*}{$\begin{array}{l}\text { Economic } \\
\text { transactions }\end{array}$} & \multicolumn{2}{|c|}{$\begin{array}{c}\text { International accounting } \\
\text { practice }[9 ; 10]\end{array}$} & \multicolumn{2}{|c|}{ Domestic accounting practice $[7 ; 12]$} \\
\hline & & measurement & $\begin{array}{l}\text { accounting } \\
\text { method }\end{array}$ & measurement & $\begin{array}{l}\text { accounting } \\
\text { method }\end{array}$ \\
\hline 1 & $\begin{array}{l}\text { Receiving goods } \\
\text { at a discount price }\end{array}$ & At the fair value & Accrual & At the original value & $\begin{array}{l}\text { At the acquisition } \\
\text { period }\end{array}$ \\
\hline 2 & Grants & At the fair value & Accrual & At the original value & Accrual \\
\hline 3 & Gifts & At the fair value & Accrual & At the fair value & Accrual \\
\hline 4 & Writing off debts & At the fair value & Accrual & At the original value & At the write-off period \\
\hline 5 & Penalties & At the fair value & Accrual & At the original value & At the receipt period \\
\hline 6 & $\begin{array}{l}\text { Donations (charitable } \\
\text { contributions) }\end{array}$ & At the fair value & Accrual & $\begin{array}{l}\text { At the original or fair } \\
\text { value }\end{array}$ & Accrual \\
\hline
\end{tabular}

On the outcome of reformed budget accounting, revenue measurement is considered in the context of the category "economic benefit" and "service potential" - one of the most controversial concepts in terms of their professional estimation and documentation in practice.

Art. 1 of the Law of Ukraine "On Accounting and Financial Reporting in Ukraine" (hereinafter referred to as the Law) defines economic benefits as "a potential opportunity for the enterprise to obtain cash from the use of assets" [13]. Accordingly, to estimate the real solvency (availability of cash), it is necessary to single out the accrued and/or received economic benefits on the outcome of the completed business transaction.

The Law identifies economic benefits as monetary. At the same time, "service potential" in NPSAS 121 "Fixed assets" is defined as "the present and potential opportunities that a public sector accounting entity receives from the use of assets that do not directly generate cash inflows to achieve its objective, and/or satisfaction of needs" [11].

We will clarify the definition "service potential" in the economic interpretation through the combination of components - potential and service:

- service: an economic concept that covers the qualitative and quantitative characteristics of the impact on the performance of the economic system;

- potential - the resources available to the entity, their optimal structure and the ability to use them rationally to achieve the set goal [14].

Thus, service potential is the justification of the economic efficiency of time use of resources according to their specific purpose (which confirms that it lawful for the entity to keep them on the balance sheet).

Accordingly, economic benefit is the realization of service potential.

This does not contradict IPSAS 1 "Presentation of Financial Statements", in which economic benefit and service potential are identified through the use of assets:

1) assets used to provide goods and services in accordance with the objectives specified by the entity, but which do not directly generate cash inflows, are often identified as having "service potential"; 
2) assets used to generate cash inflows are often described as assets representing "future economic benefits" [10].

Detailing the time, form, intended use of the received economic benefit in the form of assets causes the need for a qualitative expansion of the measurement of revenue recognition through the valuation:

- economic benefits - cash inflows received (to be received) as a result of transactions of an entrepreneurial nature. It should be noted that budget institutions can carry out such transactions which bear non-profitability attribute (for HEIs this is their own revenue, that is resources from the special fund);

- socio-economic benefits - economic benefits, measurement of which takes into account both direct acquisition of assets, as well as a documented measurement of the impact of the transaction on enhancing economic benefits on the outcome of the social program implementation;

- socio-economic effect - intangible socio-economic benefits received by economic entities through the measurement of the prevention and reduction of losses (including transactional), as well as the receipts expected as an outcome of such expenses.

The following conclusions can be drawn:

1. Among the discussed issues related to implementing reformed budget accounting of revenues of budget institutions (including HEIs) are the classification of revenues from exchange and non-exchange transactions. The classification of exchange revenues in terms of budget allocations in Section II, NPSAS 124, "Revenues", is not fully consistent with the norms of IPSAS 9 "Revenue arising from Exchange Transactions": received budget allocations by spending units to ensure their activities are not identified with the sale/purchase of assets in exchange for cash.

This is confirmed by the definition of the term "budget allocations", which is "the authority of the public sector entity granted in accordance with the budget assignment to take budget obligations and make payments with quantitative, time and objective restrictions" (Article 2 of the Budget Code of Ukraine). Thus, the methodology for their classification as revenues in the context of exchange and non-exchange transactions needs to be clarified.

2. The methodology for the measurement of revenues, presented in NPSAS 124 is not sufficiently consistent with the regulatory approaches regarding the formation and use of budgetary funds under budget programs. Separate sources of revenues, the accounting of which is regulated in NPSAS 124, do not correspond to the educational practice of HEIs.

In practice, HEIs can receive budgetary funds to carry out financial and economic activities (based on estimates of revenues and expenses / expenditures previously agreed with the key spending unit - the Ministry of Education and Science of Ukraine), as well as to execute / financially support certain areas of educational and scientific activity. In the first place, it is necessary to pay attention to the financing of various scholarship programs. Such revenues for HEIs do not envisage an equivalent coverage of the costs for training scholarship holders, and 
therefore require normative regulations as revenues from non-exchange transactions. Since the economic substance of the scholarship is a social support in monetary terms in accordance with the criteria determined by the key spending unit (progress, social protection, scientific achievements, etc.), such revenues should be recognized as a form of transfer budget funds.

3. The practice of the first stages of the implementation of NPSAS is not fully in line with IPSASs in terms of revenue recognition from transfer transactions: the current regulatory framework stipulates the recognition of transfer funds from the budget at the time of their receipt without requirements regarding the equivalence of valuation of services / goods realized on received budget funds.

4. Analysis of the international accounting practice of revenue recognition in the context of exchange and non-exchange operations has confirmed the existence of differences between NPSAS 124 "Revenues" and the relevant International Accounting Standards. Consequently, the discussion is to combine these types of revenues into one national accounting standard.

\section{References}

1. Ministry of Education and Science of Ukraine. (2018). Consolidated report of the Ministry of Education and Science for 2017. Retrieved from https://mon.gov.ua/storage/app/ media/budzhet/2018/04/03/zvit-mon-za-2017-rik.pdf [in Ukrainian].

2. Atamas, P. Y. (2009). Accounting at budgetary institutions. Retrieved from http:// westudents.com.ua/knigi/50-oblk-u-byudjetnih-py.html [in Ukrainian].

3. Artemenko, N. V. (2012). Areas of reforming budget accounting. Retrieved from http:// vestnik.kpi.kharkov.ua/files//2012/S16.pdf [in Ukrainian].

4. Doroshenko, O. O. (2012). Reserves of budgetary institutions: a comparative analysis of modern accounting practices and national accounting provisions (standards) in the public sector. Independent auditor, 2, 50-54 [in Ukrainian].

5. Svirko, S. V., Osadcha, O. O. (2011). Income from business and non-business activities: recognition and accounting in the context of national economic reforms. National university "Ostroh Academy" scientific papers. Economics, 18, 227-235 [in Ukrainian].

6. Romashchenko, K. M., Romashchenko, T. I. (2014). Pricing for educational services in state higher educational institutions. Investments: practice and experience, 7, 83-85 [in Ukrainian].

7. Ministry of Finance of Ukraine. (2010). National Public Sector Accounting Standard 124 "Revenues". (Order No. 1629, December 24). Retrieved from https://zakon.rada.gov.ua/ laws/show/z0089-11 [in Ukrainian].

8. IFAC. (2001, July). International Public Accounting Standard 9 "Revenue from Exchange Transactions". Retrieved from http://195.78.68.18/minfin/control/uk/archive/ docview?typeId $=81038 \&$ sortBy $=0$.

9. IFAC. (2009). International Public Sector Accounting Standard 23 "Income from NonExchange Transactions (Taxes and Transfers)". Retrieved from http://195.78.68.18/minfin/ control/uk/archive/docviewpeId [in Ukrainian].

10. IFAC. (2006, December). International Public Sector Accounting Standard 1 "Presentation of Financial Statements". Retrieved from http://195.78.68.18/minfin/control/ uk/archive/docview?typeId=81038\&sortBy $=0$.

11. Ministry of Finance of Ukraine. (2010). National public sector accounting standards 121 "Fixed assets" (Order No. 1629, December 24). Retrieved from http://www.minfin.gov. ua/control/uk [in Ukrainian]. 
12. Ministry of Finance of Ukraine. (2009). National Public Sector Accounting Standard 101 "Presentation of Financial Statements" (Order No. 1541, December 28). Retrieved from http://zakon.rada.gov.ua/cgi-bin/laws/main.cgi?nreg=z0095-11 [in Ukrainian].

13. Verkhovna Rada of Ukraine. (1999). On accounting and financial reporting in Ukraine (Act No. 996-XIV, July 16). Retrieved from https://zakon.rada.gov.ua/laws/ show/996-14 [in Ukrainian].

14. Mocherny, S. V. (Ed.). (2000). Economic Encyclopedia (Vol. 1). Kyiv: Publishing Center "Academy" [in Ukrainian].

\section{Список використаних Ажерел}

1. Консолідований звіт МОН за 2017 рік / Міністерство освіти і науки України. URL: https://mon.gov.ua/storage/app/media/budzhet/2018/04/03/zvit-mon-za-2017-rik.pdf.

2. Атамас П. Й. Облік у бюАжетних установах. 2009. URL: http://westudents.com. ua/knigi/50-oblk-u-byudjetnih-py.html.

3. Артеменко H. В. Напрямки реформування бюджетного обліку. 2012. URL: http://vestnik.kpi.kharkov.ua/files//2012/S16.pdf.

4. Аорошенко О. О. Запаси бюАжетних установ: порівняльний аналіз сучасної об-

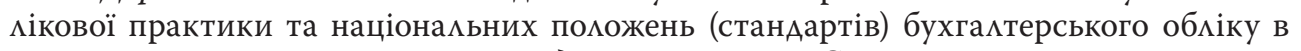
Аержавному секторі. Незалежний аудитор. 2012. № 2. С. 50-54.

5. Свірко С. В., Осадча О. О. Аоходи піАприємницької та непіАприємницької Аіяльності: визнання та облікова оцінка в умовах національних економічних реформ. Наукові записки Національного університету "Острозька академія". Сер.: Економіка. 2011. Вип. 18. С. 227-235.

6. Ромащенко K. М., Ромащенко Т. I. Ціноутворення на освітні поскуги в державних вищих навчальних закладах. Інвестицї̈: практика та досвід. 2014. № 7. С. 83-85.

7. Національне положення (стандарт) бухгалтерського обціку в державному секторі 124 “Аоходи”. URL: https://zakon.rada.gov.ua/laws/show/z0089-11.

8. Міжнародний стандарт бухгалтерського обліку в державному секторі 9 "АохіА віА операцій обміну". URL: http://195.78.68.18/minfin/control/uk/archive/docview?typeId= 81038\&sortBy $=0$.

9. Міжнародний стандарт бухгалтерського обліку в державному секторі 23 “АохіА віА необмінних операцій (податки та трансферти)”. URL: http://195.78.68.18/minfin/ control/uk/archive/docviewpeId.

10. Міжнародний стандарт бухгалтерського обліку в державному секторі 1 "Подання фінансових звітів". URL: http://195.78.68.18/minfin/control/uk/archive/docview?typeId= 81038\&sortBy $=0$.

11. Національне положення (стандарт) бухгалтерського обліку в державному секторі 121 “Основні засоби” : затв. наказом Міністерства фінансів України від 24.12.2010 № 1629. URL: http://www.minfin.gov.ua/control/uk.

12. Національне положення (стандарт) бухгалтерського обціку в Аержавному секторі 101 "Подання фінансової звітності" : затв. наказом Міністерства фінансів України віА 28.12.2009 № 1541. URL: http://zakon.rada.gov.ua/cgi-bin/laws/main.cgi?nreg= z0095-11.

13. Про бухгалтерський облік та фінансову звітність в Україні : закон України віА 16.07.1999 № 996-XIV. URL: https://zakon.rada.gov.ua/laws/show/996-14.

14. Економічна енциклопедія : У 3 т. Т. 1 / Редкол.: С. В. Мочерний (віАп. реА.) та ін. Київ : Видавничий центр “Академія”, 2000. 864 с. 